\title{
nature
} medicine

\author{
VOLUME 8 • NUMBER 2 • FEBRUARY 2002
}

\section{Health and wealth}

It seems staggering that a sum as small as $\$ 34$ per capita in developing nations would be sufficient to improve healthcare to such an extent that 8 million lives per year could be saved by 2010 and the economies of those countries radically improved by a consequently more productive workforce. Yet, this is precisely the figure arrived at by a team of 18 world-renowned economists and public health experts after two years of analysis.

The Commission on Macroeconomics and Health was set up by World Health Organization (WHO) Director-General, Gro Harlem Brundtland, to assess the place of health in global economic development. It's 210 pages detail everything from constraints to scaling up health interventions in Chad, to mental illness and the labor market in developing nations and the economic burden of malaria. Its overarching theme is that the world's poorest countries are becoming poorer because of poor health. It recommends a plan of action through which both developed and developing countries increase their heal th expenditure to achieve long-term, global economic improvement.

The report, Investing in Health for Economic Development (http://www3. who.int/whosis/menu.cfm?path =whosis,cm h\&language $=$ english), shows how just a few health conditions-HIV/AIDS, malaria, tuberculosis, childhood infectious diseases, micronutrient deficiencies and tobacco-related illnesses-are responsible for the majority of avoidable deaths in poor countries. It also gives the cost of treating these diseases. For example, the annual extra expenditure per capita for TB treatment is only 10 cents, for HIV medicines the extra cost is $\$ 1.20$. Summing such figures lead the Commission to conclude that donor contributions would have to be raised from the current $\$ 6$ billion per year to $\$ 27$ billion per year by 2007 in order to generate economic benefits of more than $\$ 360$ billion per year by 2015-2020. An economic no-brainer.
Sadly, foreign aid is too often seen as wasteful, and the easiest and most glib reaction to the report is that it is too idealistic. It requires that developing nations will cooperate and redirect a substantial proportion of their income, up to $6.8 \%$ GDP, to healthcare interventions. From past experience, this is an extremely high expectation given the political realities. Examples such as the current investigation into the millions of public dollars embezzled by Zimbabwean president Robert Mugabe, or the South African government's refusal to implement a policy of nevirapine treatment for pregnant HIV-infected women, not to mention the civil wars in subSaharan Africa that make basic childhood immunization programs a struggle, play right into the hands of even the mildest skeptics.

But of course, political corruption is not confined to developing nations, and this issue should not detract from the central message that increased spending on healthcare is not just the best investment that we can make, it'stheright thing to do.

The Commission was chaired by Jeffrey Sachs, an economics professor from Harvard University who has revitalized public health thinking since he brought his financial mind to it. The Commission also recommends that a new Global Research Fund of $\$ 3$ billion becreated to finance research into tropical diseases (see page 96). Of course, extra money does not guarantee favorable biomedical results with a parallel advance in human therapy. Yet if we do not spend the money we can be certain that there will be no improve ment.

If this was a proposal for a new company requiring a $\$ 27$ billion investment, one would need to see an extremely detailed business plan before putting the money into the project. That is what Sachs $\&$ Co. have provided. Now they need support in convincing investors, beginning with the biggest, Capitol Hill. But despite the best efforts of Colin Powell and Bill
Frist, the reaction in Washington so far has been lukewarm. Perhaps there are two reasons for this: the report's timing and its backer.

The timing is just bad luck. In the postSeptember 11 world of financial cautiousness, everyone from individual consumers to multinational corporations is keeping tighter control over their budgets fearing a global recession. A case in point is the current reluctance of some developed nations to pay their dues to the World Bank's International Development Association fund, which loans money to the world's poorest countries. According to the 15 January Financial Times, the World Bank has asked for $\$ 12.5$ billion in new money over 3 years, but France, Japan and Germany are citing new domestic budgetary pressure and asking for a reduction in contributions. However, the terrorist attacks have also re-ignited popular sentiment that global development is now imperative to worldwide stability, rather than merely a moral comfort.

In addition, many believe that if the report had been written under the auspices of any organization other than the WHO, it would be far better received. Brundtland has worked hard to shed the image of a lumbering and inefficient bureaucracy precisely by initiating innovative projects such as this one, but memories are hard to erase, especially when money is involved.

However, we believe that the report is truly groundbreaking. There have been relatively few attempts to document the cost of treating disease to yield economic growth. Some examples now exist for the AIDS crisis (Nature Med. 7, 521; 2001 and Science 292, 2434; 2001), but this report goes well beyond a single example. Thus, it will likely remain the best set of figures linking health to wealth for years to come and everyone who claims to have an interest in public health and welfare should read it and lend their support in any way they can. 